\title{
ANALYSIS OF ACTIVE LEARNING IN SCHOOL (ALIS) ON BIOLOGY SUBJECT AT SENIOR HIGH SCHOOL IN SALATIGA
}

\section{ANALISIS ACTIVE LEARNING IN SCHOOL (ALIS) PADA \\ PEMBELAJARAN BIOLOGI SEKOLAH MENENGAH ATAS (SMA) DI SALATIGA}

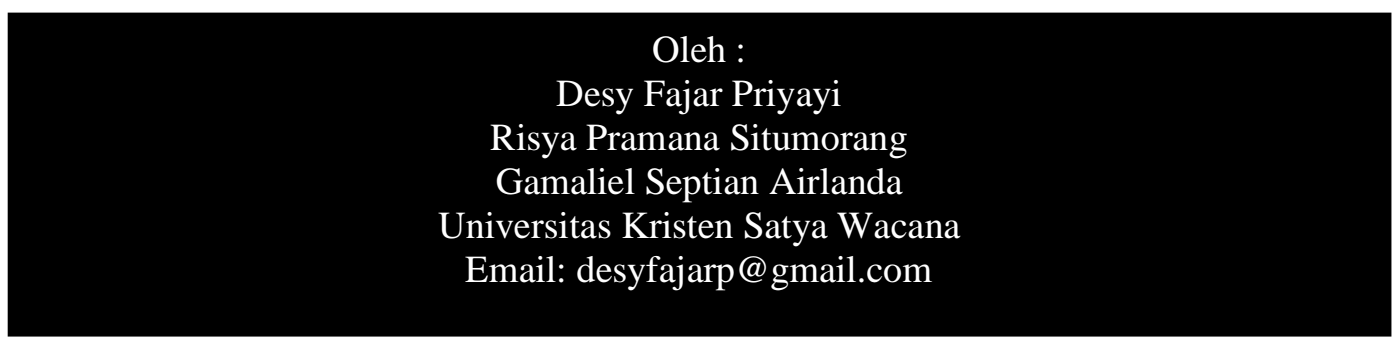

Abstract, Active learning in school (ALIS) is one of the learning models that can be applied by teachers to improve students' achievement. This study aims to determine the implementation of ALIS indicator on biology subject at senior high school in Salatiga and to know the factors that influence it. This is a descriptive qualitative research and the data was collected using questionnaires, observation, interview, and documentation technique. The objects of study were 156 students and 5 biology teachers at five senior high schools in Salatiga. The results showed the percentage of ALIS indicators from low level to high were: learning to encourage students to interact multidirectional (60.42\%); using the environment as a medium and learning resources (64.94\%); maintaining the learning environment (65.81\%); learning encourages student to think at high level (66.11\%); student-centered learning (66.91\%); there are feedback on student work $(70.47 \%)$; monitoring the learning process by teacher (71.04\%); contextual learning (73.63\%); learning model accommodate different learning style (75.71\%). Biology teachers in Salatiga have been implementing ALIS but there are some factors influence it which include lack of time to study with so many subject materials, inadequate facilities and infrastructure, and the students' unfamiliarity with the application of active learning.

Keywords: ALIS, active learning, biology teaching and learning

Abstrak, Active learning in school (ALIS) merupakan salah satu pilihan model pembelajaran yang dapat diterapkan oleh guru dan memberikan dampak positif kepada siswa. Penelitian ini bertujuan untuk mengetahui penerapan indikator ALIS pada mata pelajaran biologi sekolah menengah atas (SMA) di Salatiga dan faktor-faktor yang mempengaruhinya. Penelitian ini merupakan penelitian deskriptif kualitatif dengan teknik pengumpulan data menggunakan angket, observasi, wawancara dan dokumentasi. Obyek penelitian adalah 156 siswa dan 5 guru biologi yang tersebar di lima Sekolah Menengah Atas (SMA) kota Salatiga. Hasil penelitian menunjukkan persentase keterlaksanaan indikator ALIS dari tingkat rendah ke tinggi adalah: pembelajaran mendorong siswa untuk berinteraksi multiarah $(60,42 \%)$, pembelajaran penggunaan lingkungan sebagai media dan sumber belajar $(64,94 \%)$, adanya penataan lingkungan belajar $(65,81 \%)$, pembelajaran mendorong anak untuk berpikir tingkat tinggi $(66,11 \%)$, pembelajaran berpusat pada siswa $(66,91 \%)$, adanya umpan balik terhadap hasil kerja siswa $(70,47 \%)$, pemantauan proses belajar oleh guru $(71,04 \%)$, pembelajaran terkait dengan kehidupan nyata $(73,63 \%)$, pembelajaran mengakomodasi gaya belajar yang berbeda-beda (75,71\%).Guru biologi di Salatiga telah melaksanakan ALIS, namun terdapat beberapa hambatan antara lain: keterbatasan waktu dengan tuntutan banyaknya materi, terbatasnya sarana dan prasarana, dan belum terbiasanya siswa menerapkan pembelajaran aktif.

Kata Kunci: ALIS, pembelajaran aktif, pembelajaran biologi 


\section{A. PENDAHULUAN}

Undang-Undang Nomor 20 Tahun 2003 tentang Sistem Pendidikan Nasional, Pasal 1 ayat 1 menyatakan bahwa pendidikan adalah usaha sadar dan terencana untuk mewujudkan suasana belajar dan proses pembelajaran agar peserta didik secara aktif mengembangkan potensi dirinya untuk memiliki kekuatan spiritual keagamaan, pengendalian diri, kepribadian, kecerdasan, akhlak mulia, serta keterampilan yang diperlukan dirinya, masyarakat, bangsa dan negara.Tercapainya tujuan dari pendidikan nasional menjadi tanggung jawab semua pihak, termasuk guru. Guru tidak hanya berperan sebagai pengajar, melainkan juga sebagai fasilitator dan motivator. Guru memiliki tugas untuk merancang pembelajaran yang interaktif, inspiratif, menyenangkan, menantang, dan memotivasi siswa untuk berpartisipasi aktif (Permendikbud No.65 tahun 2013). Pembelajaran diharapkan tidak lagi menjadikan guru sebagai satusatunya sumber dalam belajar.

Banyak faktor yang mempengaruhi kualitas dari suatu pembelajaran termasuk di dalamnya pendekatan, model, strategi atau metode yang digunakan guru dalam mengajar. Salah satu pendekatan yang dapat diterapkan untuk meningkatkan hasil belajar dan partisipasi siswa adalah pendekatan pembelajaran aktif (Zimudzi, 2012). Pembelajaran aktif merupakan pendekatan pembelajaran yang memandang siswa sebagai subyek belajar. Siswa dapat membangun pengetahuannya secara mandiri melalui pengalaman-pengalaman yang telah dialami langsung. Pembelajaran aktif bukanlah tujuan dari kegiatan pembelajaran tetapi merupakan salah satu strategi yang digunakan untuk mengoptimalkan proses pembelajaran (Uno, 2011:10). Konsep pembelajaran aktif dipandang sesuai dengan kondisi saat ini dan dapat memberikan dampak positif kepada siswa (Silberman, Mel1996; Prince, 2004; Gao dan Hargis, 2010; Hazzan, 2011).

Di Indonesia, pembelajaran aktif berkembang pada tahun 1980-an sebagai pendekatan cara belajar siswa aktif (CBSA). Seterusnya perkembangan kurikulum masih menerapkan pembelajaran aktif dalam perkembangannya. Sejak tahun 2007, dikenal istilah active learning in school (ALIS) sebagai salah satu program pelatihan pembelajaran aktif hasil 
kerjasama dengan program Berdasarkan hal tersebut, maka perlu Decentralize Basic Education 2 dilakukan penelitian dengan judul “ (DBE2). Analisis Active Learning in School

Karakteristik pembelajaran aktif menurut panduan ALIS dalam Uno (2012) antara lain: 1) pembelajaran berpusat pada siswa, 2) pembelajaran terkait dengan kehidupan nyata, 3) pembelajaran mendorong siswa untuk berpikir tingkat tinggi, 4) pembelajaran mengakomodasi gaya belajar siswa yang berbeda-beda, 5) pembelajaran mendorong anak untuk berinteraksi multiarah, 6) pembelajaran menggunakan lingkungan sebagai media atau sumber belajar, 7) penataan lingkungan belajar yang memudahkan siswa untuk melakukan kegiatan belajar, 8) guru memantau proses belajar siswa, 9) guru memberikan umpan balik terhadap hasil kerja siswa.

Pembelajaran aktif di sekolah atau sering disebut dengan istilah ALIS telah banyak disosialisasikan kepada guruguru sebagai upaya untuk memperbaiki mutu pembelajaran, termasuk dalam pembelajaran biologi. Namun, dalam taraf implementasinya belum diketahui bagaimana penerapan masing-masing dari indikator ALIS, baik menurut pandangan guru maupun siswa. (ALIS) pada Mata Pelajaran Biologi Sekolah Menengah Atas (SMA) di kota Salatiga".

Tujuan dari penelitian ini adalah: 1) mengetahui penerapan indikator ALIS pada mata pelajaran biologi SMA di Salatiga, 2) mengetahui faktor-faktor yang mempengaruhi penerapan ALIS. Hasil analisis dari penerapan ALIS diharapkan dapat menjadi evaluasi dan umpan balik pembelajaran bagi guru, sekolah maupun pihak lainnya untuk memperbaiki kualitas pembelajaran.

Penelitian ini merupakan penelitian deskriptif kualitatif yang dilakukan terhadap variabel mandiri. Peneliti tidak memberikan perlakuan terhadap obyek. Teknik pengumpulan data yang digunakan adalah angket, observasi, wawancara dan dokumentasi. Obyek penelitian adalah 156 siswa dan 5 guru biologi yang tersebar di lima Sekolah Menengah Atas (SMA) kota Salatiga. Analisis data dilakukan secara deskriptif dengan teknik persentase.

\section{B. HASIL DAN PEMBAHASAN}

Pembelajaran aktif merupakan pembelajaran yang melibatkan pikiran 
siswa secara aktif sehingga siswa dapat bertindak sebagai penghasil pengetahuan (Bellanca, J, 2011). Pembelajaran aktif merupakan sebuah proses yang melibatkan secara aktif dalam membangun pemahaman tentang fakta, ide, dan keterampilan melalui berbagai tugas dan aktivitas (Kahrhoff, J, Bell, D, 2006). Prinsip pembelajaran aktif berkembang dari prinsip tabula rasa (1960-an) oleh John Locke yang menyatakan bahwa pengetahuan berasal dari pengalaman. Dengan kata lain, untuk memperoleh pengetahuan seorang siswa harus mengalami proses pembelajaran sendiri. Selain itu, pada John dewey banyak menjelaskantentang teori learning by doing atau belajar dengan melakukan, (Warsono, Hariyanto, 2013).

Teori yang mendasari konsep pembelajaran aktif adalah teori pembelajaran konstruktivis yang beranggapan bahwa belajar sebagai proses pembentukan (konstruksi) oleh pebelajar sendiri. Di Indonesia, pembelajaran aktif berkembang pada tahun 1980-an sebagai pendekatan cara belajar siswa aktif (CBSA). Seterusnya perkembangan kurikulum masih menerapkan pembelajaran aktif dalam perkembangannya. Sejak tahun 2007, dikenal istilah active learning in school (ALIS) sebagai salah satu program pelatihan pembelajaran aktif hasil kerjasama dengan program decentralize basic education 2 (DBE2). Dapat disimpulkan bahwa ALIS adalah model pembelajaran yang mengkondisikan siswa untuk melakukan suatu pengalaman belajar yang bermakna dan berpikir tentang apa yang dapat dilakukannya selama pembelajaran.

1. Keterlaksaan ALIS pada mata pelajaran biologi di Salatiga

Hasil pengamatan pada Gambar 1. menunjukkan secara berurutan tingkat keterlaksanaan indikator ALIS pada pembelajaran biologi SMA di Salatiga dari rendah ke tinggi adalah: pembelajaran mendorong siswa untuk berinteraksi multiarah, pembelajaran menggunakan lingkungan sebagai media dan sumber belajar, adanya penataan lingkungan belajar, pembelajaran mendorong siswa untuk berpikir tingkat tinggi, pembelajaran berpusat pada siswa, adanya umpan balik terhadap hasil kerja siswa, pemantauan proses belajar oleh guru, pembelajaran terkait dengan kehidupan nyata, pembelajaran mengakomodasi gaya belajar yang berbeda-beda. 
Tabel 2.1 Rata-rata Persentase Keterlaksanaan Indikator ALIS

\begin{tabular}{|c|c|c|c|}
\hline No & Indikator & Mean & Standar \\
\hline & & $(\%)$ & Deviasi \\
\hline 1. & 1 & 66.91 & 12.34 \\
\hline 2. & 2 & 73.63 & 10.47 \\
\hline 3. & 3 & 66.11 & 11.90 \\
\hline 4. & 4 & 75.71 & 12.48 \\
\hline 5. & 5 & 60.42 & 20.21 \\
\hline 6. & 6 & 64.94 & 13.89 \\
\hline 7. & 7 & 65.81 & 9.28 \\
\hline 8. & 8 & 71.04 & 12.94 \\
\hline 9. & 9 & 70.47 & 12.02 \\
\hline & & & \\
\hline 50 & & & \\
\hline 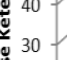 & & & \\
\hline 201 & & & \\
\hline & 23 & $\begin{array}{c}5 \\
\text { dikator AlS }\end{array}$ & 89 \\
\hline
\end{tabular}

\section{Gambar 2.1 Persentase Keterlaksanaan Indikator ALIS}

Keterangan :

a. Pembelajaran berpusat pada siswa

b. Pembelajaran terkait dengan kehidupan nyata

c. Pembelajaran mendorong anak untuk berpikir tingkat tinggi

d. Pembelajaran mengakomodasi gaya belajar yang berbeda-beda

e. Pembelajaran mendorong siswa untuk berinteraksi multiarah

b. Pembelajaran menggunakan lingkungan sebagai media dan sumber belajar

a. Penataan lingkungan belajar

b. Pemantauan proses belajar oleh guru

c. Umpan balik terhadap hasil kerja siswa

Keterlaksanaan indikator adanya sebesar 60,42 \%. Rendahnya pembelajaran yang mendorong siswa keterlaksanaan indikator didukung oleh untuk berinteraksi multiarah adalah hasil pengamatan bahwa guru masih 
menerapkan pembelajaran yang bersifat satu arah dari guru ke siswa. Guru menjelaskan materi dan siswa mencatat apa yang dijelaskan

Idealnya, dalam penerapan ALIS, belajar tidak hanya bertujuan untuk mencapai penguasaan materi pelajaran, namun juga mempersiapkan siswa untuk bersiap diri menjadi bagian dari masyarakat (learning to live together). Siswa perlu mengembangkan kemampuan untuk berinteraksi dengan individu lain, baik siswa maupun guru. Bellanca, J (2011) menyatakan guru pembelajaran aktif harus merancang kegiatan yang melibatkan siswa dalam tugas dan kerjasama. Guru dapat membentuk kelompok-kelompok siswa secara heterogen sesuai dengan kemampuan akademis, jenis kelamin, minat, kecerdasan, maupun gaya belajar. Kerja sama yang dilakukan merupakan kerjasama kolaboratif. Artinya, siswa tidak hanya belajar untuk bekerja sama saja tetapi juga harus bertanggung jawab kepada teman satu kelompoknya dalam tercapainya pengetahuan yang merata (Barkley, 2005).

Indikator ALIS berikutnya adalah penggunaan lingkungan sebagai media dan sumber belajar dengan persentase keterlaksanaan sebesar 64,94\%. Lingkungan menjadi media pembelajaran berarti bahwa lingkungan berfungsi sebagai pengantar dan penyalur pesan yang mampu merangsang pikiran, perasaan, perhatian, dan keinginan siswa untuk belajar, sedangkan lingkungan dikatakan sebagai sumber belajar apabila lingkungan tersebut menjadi hal yang dapat dipelajari. Siswa dapat mengeksplorasi lingkungan untuk memperoleh informasi baru dan dipadukan dengan pengetahuan yang telah dimiliki oleh siswa. Keterlaksanaan indikator yang masih rendah disebabkan karena tuntutan banyaknya materi yang harus dikuasai siswa, guru lebih memilih buku (textbook) sebagai sumber belajar yang utama.

Pembelajaran aktif memerlukan adanya penataan lingkungan belajar. Lingkungan dapat berupa lingkungan secara fisik, lingkungan sosial, lingkungan budaya dan lingkungan mental. Lingkungan berkaitan dengan kondisi eksternal di sekitar siswa yang mendukung proses pembelajaran. Berdasarkan hasil pengamatan persentase keterlaksaannya cukup 
rendah yaitu sebesar $65,81 \%$. Secara fisik, guru tidak banyak melakukan penataan lingkungan. Posisi kursi masih didominasi oleh posisi klasikal. Idealnya, lingkungan yang dapat memberikan suasana kondusif untuk kegiatan belajar-mengajar, tanpa ada ketegangan antara guru dan siswa, dapat meningkatkan penyampaian instruksional yang baik dan hasil belajar yang lebih baik pula (Ajayi,2011). Adanya rasa nyaman dengan guru dan siswa lain dapat mengembangkan kepercayaan diri siswa dan kemampuan untuk menyampaikan ide dan pendapat (Liu, 2012).

Penerapan ALIS harus mendorong anak untuk berpikir tingkat tinggi. Keterlaksanaan dari indikator ini adalah sebesar $66,11 \%$. Kemampuan berpikir yang dikembangkan dalam pembelajaran aktif antara lain: kemampuan berpikir kritis, berpikir kreatif, dan pemecahan masalah. Berpikir kritis adalah kemampuan untuk melakukan analisis, menciptakan dan menggunakan kriteria secara obyektif, dan melakukan evaluasi data. Berpikir kreatif merupakan kemampuan untuk menggunakan struktur berpikir yang rumit untuk mengahasilkan ide yang baru dan orisinal. Sedangkan kemampuan pemecahan masalah merupakan kemampuan berpikir secara kompleks untuk memecahkan suatu masalah. (Gunawan, 2003). Sebagian guru telah mencoba untuk mengembangkan kemampuan berpikir tingkat tinggi siswa melalui adanya penugasan-penugasan dan pertanyaan evaluasi, namun hanya sebagian siswa saja yang dapat mengikuti.

ALIS merupakan pembelajaran yang berpusat pada siswa. Persentase keterlaksanaan dari indikator ini adalah sebesar 66,91\%. Pembelajaran berpusat pada siswa berarti adalah pembelajaran yang menjadikan siswa sebagai subyek belajar. Guru tidak lagi menjadi satusatunya sumber dalam belajar. Thanh, $\mathrm{P}$ (2010) berpendapat tentang karakteristik pemebelajaran yang berpusat pada siswa antara lain: siswa memiliki tanggung jawab individu pada diri sendiri dan individu lain, adanya manajemen penugasan, dan pembangunan konsep secara mandiri melalui kelompok belajar. Wenno, IH (2008) menyatakan karakter guru sains yang menerapkan pembelajaran berpusat pada siswa antara lain: guru mengakui dan menghargai keunikan masing-masing siswa, guru memahami bahwa belajar adalah proses 
konstruktivis, guru dapat menciptakan iklim pembelajaran yang positif, guru memulai pembelajaran dengan asumsi bahwa semua siswa dengan kondisinya bersedia untuk belajar serta memiliki minat dan motivasi untuk mengembangkan pengetahuannya.

Karakteristik ALIS yang lain yaitu adanya umpan balik terhadap hasil kerja siswa. Persentase keterlaksanaannya adalah sebesar $70,47 \%$. Umpan balik dilakukan guru dengan memberi tanggapan atau solusi atas permasahalan yang dihadapi siswa. Guru mengembalikan hasil ujian kepada siswa serta mengevaluasi dan memberikan tindak lanjut.

Penerapan ALIS mengharuskan guru untuk terus melakukan pemantauan proses belajar. Persentase keterlaksanaannya adalah sebesar $71,04 \%$. Sebagai fasilisator, guru berperan untuk membimbing siswa dalam memecahkan kesulitan. Guru perlu mengetahui hambatan-hambatan yang terjadi dan juga sejauh mana siswa menguasai konsep yang menjadi tujuan pembelajaran.

Pembelajaran ALIS merupakan pembelajaran yang terkait dengan kehidupan nyata atau kontekstual.
Pembelajaran kontekstual membantu siswa untuk menghubungkan hal yang dipelajari oleh siswa dalam kehidupan dan menerapkannya (Berns dan Erickson, 2007) Persentase keterlaksanaan dari indikator ini adalah sebesar 73,63\%. Pembelajaran kontekstual merupakan pembelajaran dengan karakteristik mengaktifkan pengetahuan yang sudah ada, menambah pengetahuan baru, mempraktekkan pengetahuan tersebut, dan adanya refleksi terhadap strategi pengembangan pengetahuan (Hamruni, 2012). Keterlaksanaan dari indikator ini cukup baik. Guru melakukan pembelajaran kontekstual dengan memberikan contoh-contoh materi hubungannya dengan kehidupan seharihari.

Pembelajaran ALIS idealnya dapat mengakomodasi gaya belajar yang berbeda-beda. Persentase keterlaksanaan dari indikator ini merupakan persentase paling tinggi yaitu sebesar $75,71 \%$.Tingginya persentase pada indikator ini menunjukkan telah adanya upaya guru untuk mengembangkan strategi mengembangkan kemampuan belajar siswa. Dengan menyadari tentang cara menyerap dan mengolah informasi, 
dapat menjadikan belajar dan konstruktivis yaitu model pembelajaran berkomunikasi lebih mudah. DePorter, inquiry, problem based learning, B and Hernacki, M (2011) menjelaskan discovery, dan project based learning. tentang tiga gaya belajar siswa. Gaya Kegiatan yang dianggap guru dapat belajar kinestetis yaitu belajar yang meningkatkan keaktifan siswa antara dengan mengalami atau melakukan lain kegiatan diskusi dan praktikum. suatu aktivitas. Gaya belajar auditori Berdasarkan hasil wawancara dapat yaitu belajar yang dilakukan melalui diketahui bahwa semua guru pernah kegiatan mendengarkan, menyimak, melaksanakan pembelajaran aktif, berbicara, presentasi, argumentasi, namun terdapat kendala dalam mengemukakan pendapat, dan pelaksanaanya, antara lain: adanya menanggapi. Gaya belajar visual yaitu keterbatasan waktu dengan tuntutan belajar yang dilakukan dengan banyaknya materi, terbatasnya sarana menggunakan indera mata melalui dan prasarana, faktor karakter siswa mengamati, menggambar, yang tidak terbiasa aktif. Pandangan mendemonstrasikan, membaca, guru tersebut masih menganggap bahwa menggunakan media dan alat peraga. penerapan ALIS merupakan sesuatu Guru biologi di Salatiga yang sulit karena memandang suatu mengakomodasi berbagai gaya belajar proses belajar dengan sintaks yang dengan menerapkan metode diskusi, panjang dan terbatasnya sarana praktikum, ceramah, penayangan video, prasarana.

dan presentasi.

2. Faktor-faktor yang mempengaruhi keterlaksanaan ALIS

Guru biologi di Salatiga mendeskripsikan ALIS sebagai pembelajaran yang mengajak siswa untuk terlibat dalam kegiatan yang merangsang proses berpikir. Contoh model pembelajaran yang dikenal guru adalah pembelajaran yang dikembangkan berdasarkan teori belajar

Berkaitan dengan tidak terbiasanya siswa dengan penerapan ALIS, guru dapat mengatasi dengan mengenalkan pembelajaran ALIS secara bertahap. Silberman, Mel (1996) telah mengembangkan metode praktis dalam menerapkan pembelajaran aktif. Dalam jangka panjang siswa akan menyadari adanya manfaat belajar secara aktif. Cooperstein (2004) menguraikan manfaat dari pembelajaran aktif sebagai 
pembelajaran konstruktivis yaitu aktivitas yang dilakukan siswa dalam pembelajaran aktif dapat membimbing siswa untuk menemukan konsep dan mengembangkan keterampilan. Konsep yang abstrak menjadi lebih bermakna, dipahami, dan mudah diingat.

\section{SIMPULAN DAN SARAN}

Keterlaksanaan indikator ALIS dari tingkat rendah ke tinggi adalah: pembelajaran mendorong siswa untuk berinteraksi multiarah (60, 42\%), pembelajaran menggunakan lingkungan sebagai media dan sumber belajar $(64,94 \%)$, adanya penataan lingkungan belajar $(65,81 \%)$, pembelajaran mendorong anak untuk berpikir tingkat tinggi $(66,11 \%)$, pembelajaran berpusat pada siswa $(66,91 \%)$, adanya umpan balik terhadap hasil kerja siswa $(70,47 \%)$, pemantauan proses belajar oleh guru $(71,04 \%)$, pembelajaran terkait dengan kehidupan nyata $(73,63 \%)$, pembelajaran mengakomodasi gaya belajar yang berbeda-beda $(75,71 \%)$. Guru biologi di Salatiga telah melaksanakan ALIS, namun terdapat faktor-faktor yang menyebabkan minimnya pelaksanaan ALIS antara lain: keterbatasan waktu dengan tuntutan banyaknya materi, terbatasnya sarana dan prasarana, dan belum terbiasanya siswa menerapkan pembelajaran aktif.

\section{DAFTAR PUSTAKA}

Ajayi, I A. and Ekundayo, H T. (2011). Factors Determining the Effective ness of Secondary Schools in Nig eria, Anthropologist. 13(1):33-38

Barkley, E.F, Cross, K.P and Major, C. H. (2005). Collaborative Learnin g Techniques.USA: Jossey-Bass.

Bellanca, J. (2011). 200+ Strategi dan P royek Pembelajaran Aktif untuk $M$ elibatkan Kecerdasan Siswa (Terj emahan). Jakarta: PT. Indeks

Berns, dan Erickson. (2001).Contextual Teaching and Learning: Preparin $g$ Students for the New Economy. The Highlight Zone: Research@ Work. No. 5, diakses 10 Juni 201 6 darihttp://www.nccte.org/public ations/infosynthesis/highlightzon e/hightlight05/highlight05-CTL.p df.

Cooperstein, Susan E dan Weidinger, E lizabeth. (2004). Beyond Active L earning:A Constructivist Approac h. Reference Services Review. 32 (2);. 141-148.

DePorter, B and Hernacki, M. (2011). $Q$ uantum Learning, Membiasakan Belajar Nyaman dan Menyenangk 
an. Bandung: Kaifa.

Gao dan Hargis, (2010). Promoting Tec hnology-assisted Active Learning in Computer Science Education. $T$ he Journal of Effective Learning ( JET), Pg 81-93.

Hamruni, (2012). Strategi Pembelajaran . Yogyakarta: Insan Madani

Hazzan, O. et al., (2011). Guide to Teac hing Computer Science: An Activi ty-Based Approach, London: Spri nger-Verlag Limited. Diakses $1 \mathrm{~J}$ uni 2016 dari http://www.springer .com/content $/ \mathrm{m} 0 \mathrm{~m} 145621 \mathrm{u} 75163$ $\underline{81}$

Kahrhoff, J, Bell, D. (2006). Active Lea rning Handbook. Missouri: Webs ter university.

Liu, Eric Zhi Feng. (2012). The Dynam ic of Motivation and Learning Str ategy in a Creativity- Supporting Learning Environment in Higher Education. TOJET: The Turkish $O$ nline Journal of Educational Tech nology. 11(1): 172-179.

Peraturan Menteri Pendidikan dan Kebu dayaan No.65 tahun 2003 tentang Sistem Pendidikan Nasional.

Prince, M.J. (2004). Does Active Learn ing Work? A Review of the Resea rch. Journal of Engineering Educ ation, 93(3). diakses 5 Mei $2016 \mathrm{~d}$ i www.nscu.edu/felder-public/Pa pers/ Prince_AL.pdf

Silberman, Mel. (1996). Active Learnin g: 101 Strategies to Teach Any Su bject. Pearson Higher Education

Thanh, P. (2010). Implementing a Stud ent-Centered Learning Approach at Vietnamese Higher Education I nstitutions: Barriers under Layers of Casual Layered Analysis (CLA ). Journal of Futures Studies. Sep tember 2010, 15(1), 21-38.

Undang-Undang Nomor 20 Tahun 2003 tentang Sistem Pendidikan Nasio nal

Uno, H. B., \& Mohamad, Nurdin. (201 2). Belajar dengan Pendekatan $P$ AILKEM. Jakarta: Bumi Aksara

Warsono, Hariyanto. 2013. Pembelajar an Aktif. Teori dan Assesment. Ba ndung: PT Remaja Rosdakarya

Wenno, IH. 2008. Strategi Belajar Men gajar Sains Berbasis Kontekstual. Yogyakarta: Penerbit Inti Media

Zimudzi, Edward. 2012. Active Learning For Problem Solving In Programming In A Computer Studies Method Course. Academic Research International.3(2):284. 